\title{
Time to speak up for climate-change science
}

\section{If debate is left to greens and sceptics, people think the evidence is equal on each side.}

Sir - The science of climate change is under attack — an attack that is coordinated, well-funded and given constant play in the media. The stronger the scientific consensus on climate change becomes, the more the media suggest that the science is uncertain.

Lobby groups such as the Scientific Alliance and the International Policy Network have sprung up to offer climate 'sceptics' to the media. In the United Kingdom, the BBC appears incapable of hosting a discussion on climate change without letting one of these people claim that it is not happening.

The impression created in the public mind is that climate scientists are deeply divided, and action to reduce greenhousegas emissions would be premature.

Yet the consensus among climatologists, glaciologists and atmospheric physicists that anthropogenic climate change is a reality - is as robust as is likely to be found on any scientific issue.

As environmental campaigners, we would like to ask climate scientists everywhere: why are we being left to carry the can?

We're not asking you to become campaigners or to compromise your independence. But we wish you would defend your profession as any other professionals would. This includes training people in media relations, sending eminent delegations to meet editors and senior journalists, writing letters to the papers to correct misleading articles and seeking every opportunity to put the record straight.

Isn't it time you started fighting for your science?

\section{George Monbiot}

82 Fairacres Road, Oxford OX4 1TG

Other signatories of this letter:

Mark Lynas 30 Ulfgar Road, Oxford OX2 $8 A Z$

George Marshall Climate Outreach Information Network

Tony Juniper Friends of the Earth UK

Stephen Tindale Greenpeace UK

\section{We Africans must take our future in our hands}

Sir - Your Editorial “Africa 2005” (Nature 433,669 ; 2005) stresses that it needs to be Africans, not donors, who decide how to spend the billions of dollars Africa is to receive in aid. But money alone is not what the continent needs for sustainable development. African countries have received billions of dollars in aid and loans during the past half century, and the result is what we have today.

The continent needs good management, relevant projects and a boost to science and technology. Regional economic integration combined with increased exports of our products and competitive investments are enough to sustain economical development.

Many people in Africa are aware of the real problems and their solutions. In 2000, when the Department of Education in Rwanda negotiated scholarships with a non-governmental organization for 100 students to study in the United States, the minister of education told us that the country needs scientists and engineers.

Before coming to the United States to study computer science under this scheme, I had always thought that Africa's underdevelopment and poverty were mainly caused by Western nations through slavery, colonization and imperialism. This concept stemmed from the information I had at the time. But even if it contains some truth, I have come to realize that the current situation depends on what we Africans are doing in our continent and on our attitudes towards international exchanges.

To help poor countries is not bad. But Western nations can't help us to become as developed as they are. I share a vision with Nature and with John Mugabe, the scientific adviser to the New Partnership for Africa's Development: the future of Africa is in the hands of Africans. Justin Hategekimana 8228 Ohio River Boulevard, Apt 45, Pittsburgh, Pennsylvania 15202, USA

\section{Driving passion brought rare bird to the masses}

Sir - Your reprinted item from 1955 concerning an expedition to Sierra Leone to find Picathartes gymnocephala (" 50 years ago" Nature 433, 23; 2005) did not mention that the team was led by a recently appointed member of BBC staff called David Attenborough.

The search formed the central plank of the Zoo Quest series, which captured the imagination of the British televisionwatching public in the 1950s and was the direct forerunner of classic programmes such as Life on Earth, which was broadcast to millions around the world.

In his autobiography Life on Air (BBC Books, London, 2002), Attenborough tells of a bus driver pulling up next to the opentop car in which he was travelling. "'Ere, Dave," called the bus driver, "are you going to find that Picafartes gymno-blinkingcephala or aren't you?"

He did — and as a result, through increased public awareness and government funding, we have all discovered much more since then. Rupert C. Marshall ${ }^{\star}$, Helen E. Nice $\dagger$ *Institute of Zoology, Gothenburg University, Medicinaregatan 18, 41390 Gothenburg, Sweden $\dagger$ Marine Monitoring Unit, Sydney Water, 51 Hermitage Road, West Ryde, 2114 NSW, Australia

\section{Authors say that they prefer online submission}

Sir - John Moore, in Correspondence (Nature 433, 800; 2005) may be right that online submission makes authors produce their own manuscripts and figures, but the evidence is that they overwhelmingly prefer this to other means.

My company is conducting a survey, commissioned by the Association of Learned and Professional Society Publishers, of recently published authors, using a sample provided by ISI. Of the 442 responses received to date, more than $80 \%$ say that online is easier than hard-copy submission. A similar number prefer online submission to any other method, and $36 \%$ say that the lack of an online system would influence them against submitting to a journal.

Respondents named a number of benefits including faster responses, shorter refereeing times, greater transparency and convenience. They did perceive areas for improvement, particularly in ease of use, system performance and flexibility, but overall they think the benefits greatly outweigh the problems.

Further, the editors and publishers we have surveyed say that the introduction of online systems leads to an increase in submissions from less-developed regions.

The full report is due to be published at the end of April.

\section{Mark Ware}

Mark Ware Consulting Ltd, 14 Hyland Grove, Westbury-on-Trym, Bristol BS9 3NR

Nature surveys all its authors immediately after publication to ask about their experience, in order to improve our services. Please contact authors@nature.com if you have any comments. 